\title{
Safety Issues With Intravenous Iron Products in the Management of Anemia in Chronic Kidney Disease
}

\author{
Amir Hayat, MD
}

\begin{abstract}
Anemia is a very common clinical problem in patients with chronic kidney disease (CKD) and is associated with increased morbidity and mortality in these patients. Erythropoietin is a hormone synthesized that is deficient in the majority of patients with advanced kidney disease, thereby predisposing these patients to anemia. The other cause of anemia is deficiency of iron. Iron deficiency anemia is common in people with CKD and its importance in supporting erythropoiesis is unquestioned, especially in those patients treated with erythropoietin. Intravenous iron is frequently used to treat anemia in CKD patients and is very efficacious in increasing hemoglobin but at the same time there are some safety issues associated with it. The objective of this review is to assess the frequency of adverse drug events associated with four different iron formulations: two iron dextran products known as high and low molecular weight iron dextran, iron sucrose, and sodium ferric gluconate complex. Several electronic databases were searched. In general, with the exception of high molecular weight iron dextran, serious or life-threatening adverse events appeared rare. Iron sucrose has the least reported adverse events and high molecular weight iron dextran has the highest number of reported adverse events. Low molecular weight iron dextran and ferric gluconate fall in between these two for number of adverse drug events.
\end{abstract}

Keywords: Anemia; Chronic kidney disease; Intravenous iron products; Safety

\begin{abstract}
A emia is a frequent and serious complication of chronic kidney disease (CKD). Erythropoiesis-stimulating agents therapy produces a dose-dependent increase in hemoglobin levels and can restore hemoglobin to normal levels if sufficient erythropoiesis-stimulating agents are administered. Iron deficiency is a frequent complication in patients with CKD. Iron deficiency blunts the response to erythropoiesis-stimulating agents. Iron losses cumulating to $2 \mathrm{~g} /$ year are typical in the hemodialysis patient and exceed normal total body stores. Given that gastrointestinal iron absorption is less than ongoing iron losses in the majority of hemodialysis patients, functional iron deficiency is likely to develop in most patients leading to iron-limited erythropoiesis.
\end{abstract}

\section{DISCUSSION}

CKD is a worldwide public health problem. In the United States, there is a rising incidence and prevalence of kidney

Reprint Requests: Amir Hayat, MD, Clinical Research Fellow Nephrology, SUNY Downstate Medical Center, 710 Parkside Avenue, Brooklyn, NY II226, Tel: 718-703-5915, Fax: 7|8-703-5935,Email: amirhayat6@hotmail.com failure. ${ }^{1}$ The number of patients enrolled in the end-stage renal disease (ESRD) Medicare-funded program has increased from approximately 10,000 beneficiaries in 1973 to 86,354 in 1983, and to 452,957 as of December $31,2003 .{ }^{2}$ In 2003 alone, 100,499 patients entered the U.S. ESRD program. The rising prevalence of treated ESRD can be attributed primarily to the increase in the number of patients who start renal replacement therapy each year, and to a smaller extent, increased survival of patients with ESRD. Patients with ESRD consume a disproportionate share of health care resources. The total cost of the ESRD program in the U.S. was approximately $\$ 27$ billion in 2003 , a $7 \%$ to $8 \%$ increase from 2002. The projected number of ESRD patients by the year 2010 has been estimated to be 661,330 and the total Medicare ESRD program cost in excess of $\$ 28$ billion dollars. ${ }^{3}$ Anemia affects $60 \%$ to $80 \%$ of patients with CKD, reduces their quality of life, and is a risk factor for early death. Treatment options are erythropoiesis-stimulating

Received: July I I, 2008

Revised: October 8, 2008

Accepted: October 17, 2008

doi: $10.312|/ \mathrm{cmr} .2008 .8| 1$ 
agents, iron administration, and blood transfusion. ${ }^{4}$ Anemia is defined by the World Health Organization (WHO) as hemoglobin concentration below $13.0 \mathrm{~g} / \mathrm{dL}$ for adult males and postmenopausal women, and a hemoglobin below $12.0 \mathrm{~g} /$ $\mathrm{dL}$ for premenopausal women. ${ }^{5}$ Anemia has also been implicated as a contributing factor in many of the symptoms associated with reduced kidney function. These include fatigue, depression, reduced exercise tolerance, dyspnea, and cardiovascular consequences such as left ventricular hypertrophy and left ventricular systolic dysfunction. ${ }^{6}$ It is also associated with an increased risk of morbidity and mortality principally due to cardiac disease and stroke, ${ }^{7,8}$ and with an increased risk of hospitalization, hospital length of stay, and mortality in patients with predialysis CKD. 9,10

\section{Etiology of Anemia in CKD}

The anemia of CKD is normocytic and normochromic. Erythropoietin deficiency, erythropoiesis inhibition, and reduction in red blood cell survival are the main causes of anemia in ESRD. ${ }^{11}$ The other cause of anemia is deficiency of iron, which occurs, in a vast majority of patients with CKD. The causes of iron deficiency in these patients are multifactorial. The main factors that contribute to iron deficiency in patients with ESRD are reduced intake and impaired intestinal absorption of dietary iron, blood losses, and/or increased iron requirements during therapy with erythropoiesis-stimulating agents. ${ }^{12}$ The dialysis patients are in a state of continuous iron loss from gastrointestinal bleeding, blood drawing, and/or, most important with hemodialysis, the dialysis treatment itself. Hemodialysis patients lose an average of $2 \mathrm{~g}$ of iron per year. ${ }^{1}$ Thus, iron deficiency will develop in virtually all dialysis patients receiving erythropoietin unless supplemental iron therapy is given orally or intravenously.

\section{Target Iron Levels}

Availability of iron is key for optimal erythropoiesis. The National Kidney Foundation-Kidney Disease Outcomes Quality Initiative Practice Guidelines recommend maintaining ferritin $\geq 100 \mathrm{ng} / \mathrm{mL}$ and transferrin saturation $\geq 20 \%$ to ensure adequate iron supply for erythropoiesis among patients with CKD, whether or not they are dialysis-dependent. ${ }^{13}$ Evaluation of iron stores should include red blood cell indices, reticulocyte count, serum iron, total iron binding capacity, percent transferrin saturation, serum ferritin, and testing for occult blood in stool. Other less commonly used indices of iron deficiency include reticulocyte hemoglobin content $<29 \mathrm{pg}$ and percentage of hypochromic red cells $<10 \%$. In patients with CKD absolute iron deficiency is defined as serum ferritin $<100(<200$ for hemodialysis patients) $\mathrm{ng} / \mathrm{mL}$ and or transferrin saturation $<20 \%$. In contrast, some patients often manifest functional iron deficiency in which serum ferritin is either normal or elevated, but transferrin saturation is $20 \%$ or less. ${ }^{14}$ Iron stores are adequate in functional iron deficiency, however, there is an inability to adequately mobilize it from the reticuloendothelial system to support erythropoiesis. Patients with functional iron deficiency anemia often respond to intravenous iron ${ }^{15}$ as opposed to a condition termed reticuloendothelial blockade, an extreme case of functional iron deficiency usually occurring in the setting of acute or chronic inflammation/infection. This often correlates with a high C-reactive protein level and/or a high erythrocyte sedimentation rate. Typically the serum ferritin level is $>200$ $\mathrm{ng} / \mathrm{mL}$ but the transferrin saturation $<20 \%$ in both conditions. Hepcidin, a peptide produced by the liver, inhibits intestinal iron absorption and the release of iron from the reticuloendothelial system to circulating transferrin. Serum levels of hepcidin are increased in the setting of inflammation/ infection, and helps explain the phenomenon of the reticuloendothelial system blockade in which stored iron is not released to circulating transferrin, resulting in a high serum ferritin and low transferrin saturation level. 16 Both functional iron deficiency and reticuloendothelial blockade may lead to erythropoietin resistance. ${ }^{17,18}$ Serum ferritin and transferrin saturation should be measured before initiating erythropoiesis-stimulating agent therapy and every 1 to 3 months during therapy. Patients with stable hemoglobin in the target range who are receiving a stable dose of an erythropoiesis-stimulating agent should have their hemoglobin checked monthly and any evidence of iron deficiency should be treated with parenteral iron as this route of administration is more effective.

Serum ferritin as a measure of iron storage in the body should be quantified every 3 months in patients who are receiving erythropoiesis-stimulating agent treatment and intravenous iron supplementation. This is required to establish whether iron deficiency exists or too much iron supplementation is being administered. The upper limit of serum ferritin at which iron treatment should be withheld is not clear. ${ }^{19}$ The Kalantar-Zadeh study ${ }^{20}$ showed no demonstrable morbidity in patients with ferritins up to $1200 \mathrm{ng} / \mathrm{mL}$. They also concluded that high serum ferritin levels in patients with ESRD may be the result of inflammation, infection, malnutrition, or malignancy, and not necessarily the result of iron overload. ${ }^{20}$ Iron deficiency in patients with ESRD probably is rare when the serum ferritin level is $>500 \mu \mathrm{g} / \mathrm{L}$ but is not excluded. ${ }^{21}$ International guidelines recommend

Table 1. Target iron levels (KDOQI: National Kidney Foundation guidelines ${ }^{23}$ ).

\section{Ferritin levels \\ Erythropoiesis-stimulating agent-treated CKD patients \\ Patients maintained on hemodialysis}

Transferrin saturation
$100-500 \mathrm{ng} / \mathrm{mL}$ 200-500 ng/mL

$20 \%$ to $40 \%$

CKD, chronic kidney disease; KDOQI, Kidney disease outcomes quality initiative 
Table 2. Available intravenous iron formulations in North America24

\begin{tabular}{lll}
\hline Generic name & Trade name & Packing \\
\hline Ferric gluconate & Ferrlecit & $62.5 \mathrm{mg} / 5 \mathrm{~mL}$ \\
Iron sucrose & Venofer & $100 \mathrm{mg} / 5 \mathrm{mlL}$ \\
Iron dextran & INFeD & $100 \mathrm{mg} / 2 \mathrm{~mL}$ \\
& Dexferrum & $100 \mathrm{mg} / 2 \mathrm{~mL}$ \\
\hline
\end{tabular}

upper limits of serum ferritin levels at $500 \mu \mathrm{g} / \mathrm{L}^{22,23}$ to avoid potential complications that are associated with iron therapy. According to the National Kidney Foundation Dialysis Outcomes Quality Initiative guidelines, the optimal ferritin target is 100 to $500 \mathrm{ng} / \mathrm{mL}$ in erythropoiesis-stimulating agent-treated CKD patients and 200 to $500 \mathrm{ng} / \mathrm{mL}$ in patients maintained on hemodialysis. Transferrin saturation is recommended to be about $20 \%$ to $40 \%{ }^{23}$ Ferritin appears to be a useless tool for demonstrating the need for iron unless absolute iron deficiency is diagnosed (table 1).

\section{Laboratory Testing}

Because iron-carbohydrate compounds interfere with clinical laboratory determination of serum iron, it follows from pharmacokinetics that serum iron and transferrin saturation should be tested after most or all of the intravenous iron agent has been cleared: no earlier than 7 days after administration of a $100 \mathrm{mg}$ dose of iron dextran, 2 weeks after a $500 \mathrm{mg}$ dose of iron dextran, and 24 to 48 hours after a $125 \mathrm{mg}$ dose of ferric gluconate or a $100 \mathrm{mg}$ dose of iron sucrose. ${ }^{24}$

\section{Nonhematological Benefits of Iron}

Iron is important for continued red blood cell production in patients treated with erythropoietin. However, iron may have a variety of nonhematological benefits. Agarwal 25 in a review of different studies mentioned the following points:

(1) Physical performance: Human studies suggest that iron deficiency without anemia may impair favorable adaptation to aerobic exercise.

(2) Thermoregulation: Iron-deficient patients with normal hemoglobin levels may have an impaired ability to maintain core body temperature in response to coldstress.

(3) Cognitive function: Iron supplementation in iron deficient subjects without anemia may result in increased cognitive function.

(4) Restless leg syndrome: Randomized control trial showed that addition of iron in hemodialysis patients with restless leg syndrome results in improvement.

(5) Immune function: Iron deficiency may result in reduced bactericidal activity of macrophages, reduced myeloperoxidase activity of neutrophils, decreased $\mathrm{T}$ lymphocyte number, blastogenesis, mitogenesis, and migration abnormalities. In addition, activated lymphocytes produce less interleukin-2. Humoral immunity appears to be less affected.
(6) Aluminum absorption: Studies show that iron depletion increases absorption and cellular uptake and suggest that individuals, such as renal failure patients, run an increased risk of toxicity if they are iron deficient.

These observations made in patients without CKD suggest the nonhematological benefits of iron supplementation. ${ }^{25}$

\section{Intravenous Iron Agents}

In functional iron deficiency, the bone marrow's erythropoietic capacity to respond to erythropoiesis-stimulating agents is limited by iron release from storage depots or by a limited capacity of plasma transport. Iron stores drop precipitously when red blood cell production accelerates following initiation of erythropoiesis-stimulating agent therapy in both non-azotemic, as well as dialysis-dependent subjects. The National Kidney Foundation-Dialysis Outcomes Quality Initiative guidelines advocate aggressive detection and management of functional iron deficiency.

Iron can be supplemented orally or intravenously. Based on the 2005 U.S. Renal Data System Annual Report, approximately $70 \%$ of hemodialysis patients in the United States receive parenteral iron. ${ }^{26}$ Intravenous iron therapy unequivocally is superior to oral iron supplementation in hemodialysis patients, ${ }^{27-29}$ peritoneal dialysis patients, ${ }^{30-32}$ and patients with CKD. ${ }^{33,34}$

Intravenous iron agents that currently are available in North America include only iron sucrose (Venofer), ferric gluconate (Ferrlecit), and two iron dextran (INFeD, Dexferrum) formulations $^{24}$ (table 2).

Iron sucrose was first used in 1949 in Europe. ${ }^{35}$ Iron sucrose is administered in intravenous push doses up to $200 \mathrm{mg}$ over 2 to 5 minutes in non-dialysis dependent patients and $100 \mathrm{mg}$ ( $5 \mathrm{~mL}$ of iron sucrose injection) administered 1 to 3 times/ week during dialysis; it is administered no more than 3 times/ week to a cumulative total dose of $1000 \mathrm{mg}$ (10 doses) in dialysis dependent patients. Iron sucrose is available in North America, Europe, and most countries worldwide. ${ }^{24}$ Based on Chandler et al study ${ }^{36}$ the 200 and $300 \mathrm{mg}$ doses of intravenous iron sucrose administered over 2 hours appear to be safe. The incidence of adverse events with the 400 and $500 \mathrm{mg}$ doses administered as a 2-hour infusion seems too high to recommend their routine use, although it may be possible to administer these doses over a longer period. 36 
Intravenous administration of ferric gluconate was first reported in 1977.37,38 Ferric gluconate has been administered $125 \mathrm{mg} / 10 \mathrm{~mL}$ over 10 minutes and up to $250 \mathrm{mg}$ over 1 to 4 hours. Most patients will require a cumulative dose of $1 \mathrm{~g}$ (1000 mg) elemental iron over approximately 8 sequential dialysis treatments to achieve a favorable response. Ferric gluconate is available in the United States and several European countries. ${ }^{24}$

There are two iron dextran products known as high and low molecular weight iron dextran. Iron dextran (Imferon) was first available in the United States and the United Kingdom for intramuscular administration in $1955^{39}$ and for intravenous use in 1971. High molecular weight iron dextran, initially marketed as Imferon (Fisons), developed a reputation for anaphylaxis, which led to its removal from the market. ${ }^{40}$ It was withdrawn from the U.S. market in 1990 and from the world market in 1996. Early reports confirmed that iron dextran could be administered in doses as high as 2 to $3 \mathrm{~g}$ given intravenously over 4 to 10 minutes. ${ }^{41}$ Low molecular weight iron dextran (InFed) was released in the mid 1990s and has a much lower incidence of anaphylactic reactions. Low molecular weight iron dextran was the standard of care for patients with anemia from hemodialysis. Shortly thereafter, another high molecular weight iron dextran product (Dexferrum) was released for clinical use. Pharmacists may confuse InFed with Dexferrum, thinking that they are equivalent products and substitute Dexferrum when InFed is prescribed under generic substitution rules. ${ }^{42}$ Dexferrum has a substantially higher risk of adverse effects than InFed. Low molecular weight iron dextran can be administered without anaphylaxis as an intravenous push of up to $200 \mathrm{mg}$ over 2 minutes or as a total-dose infusion of doses up to $3,000 \mathrm{mg}$ over 4 hours. ${ }^{43}$ In terms of cost of the total-dose infusion of low molecular weight iron dextran, this method of intravenous iron administration has been estimated to save nearly a quarter of a billion dollars in the 225,000 dialysis patients in the United States. ${ }^{44}$ In the U.S., co-administering $125 \mathrm{mg}$ of intravenous methylprednisolone before and after the infusion prevents the self-limited arthralgias and myalgias sometimes observed with larger doses of low molecular weight iron dextran. ${ }^{45}$ In Europe, premedication is not customary. ${ }^{46}$ In oncology or dialysis patients requiring weekly or more frequent visits, short infusions of low molecular weight iron dextran, iron sucrose, or ferric gluconate can be given without risk. If larger doses of intravenous iron are to be given, the preferred method is a total-dose infusion of low molecular weight iron dextran with doses up to $3,000 \mathrm{mg}$ administered in a single setting without increased toxicity.

\section{Dosing of Intravenous Iron Formulations}

Differences in pharmacokinetics among intravenous iron agents have direct implications for determining dosing frequency, treatment duration, and laboratory testing intervals. Determining dosing frequency is important as the total prescribed dose (often $1000 \mathrm{mg}$ ) is to be administered in divided doses. A reasonable dosing frequency for iron dextran agents, given plasma half-lives ranging from 30 to 60 hours, would be every 2 to 7 days, a schedule convenient for patients who are undergoing hemodialysis (one to three times weekly). However, ferric gluconate and iron sucrose with 1- and 8-hour half-lives, respectively, could be given as frequently as every 24 hours, permitting a dosing frequency more suitable for hospitalized patients. To calculate the treatment duration in days, divide the total prescribed dose (mg) by the maximum tolerated single dose (mg), and multiply by the chosen treatment interval (days). Again, in practice, actual dosing intervals may be longer than minimal for logistical reasons, just as intravenous push doses, although lower than intravenous infusion doses, may be preferred for convenience. 24

\section{Safety of Intravenous Iron Agents}

Acute Adverse Events After Intravenous Iron: Allergy or Toxic Reaction. Hamstra et $\mathrm{al}^{47}$ administered Imferon to 481 patients. Three life-threatening immediate anaphylactoid and eight severe delayed reactions were observed. There were no deaths. ${ }^{47}$ Auerbach et $\mathrm{al}^{43}$ studied the effect of total dose intravenous infusions of iron dextran and acute and delayed reactions on 87 patients. One anaphylactoid reaction and 37 transient delayed adverse reactions occurred. ${ }^{43}$

Chertow and colleagues 48 used data from the U.S. Food and Drug Administration on reported adverse drug events related to the provision of three formulations of intravenous iron, higher and lower molecular weight iron dextran, and sodium ferric gluconate complex during 1998-2000. The total number of reported parenteral iron-related adverse drug events was 1,981 among approximately 21,060,000 doses. The study concluded that adverse drug event rates were significantly higher among recipients of high molecular weight iron dextran and sodium ferric gluconate complex than among recipients of low molecular weight iron dextran. Chertow et $\mathrm{al}^{48}$ updated their study and this time used data from the U.S. Food and Drug Administration on adverse drug events attributed to the provision of four formulations of intravenous iron during 2001-2003, including higher and lower molecular weight iron dextran, sodium ferric gluconate complex, and iron sucrose. The adverse events for parenteral iron products (except Dexferrum) were all astonishingly low. Low molecular weight iron dextran, iron sucrose, and ferric gluconate can be given without significant risk with an incidence of serious adverse events of $<1$ in 200,000 . Relative to low molecular weight iron dextran, total and life-threatening adverse drug events were significantly more frequent among recipients of high molecular weight iron dextran and significantly less frequent among recipients of sodium ferric gluconate complex and iron sucrose. The absolute rates of life-threatening adverse drug events were $0.6,0.9,3.3$ and 11.3 per million for iron sucrose, sodium ferric gluconate complex, low and high molecular weight iron dextran, respectively. The authors also postulate that these rates probably overstate the risk for InFed and understate it for Dexferrum because in some cases, the adverse reports did not identify the product used. The paper 
also points out the substantially higher costs for Venofer that it would cost $\$ 7.8$ million to prevent a single life-threatening adverse event and $\$ 33$ million to prevent a single death by substituting Venofer for InFed just for the U.S. hemodialysis program alone. There is no advantage to high molecular weight iron dextran over low molecular weight iron dextran in terms of efficacy or cost. Safety concerns should lead to consideration of restricted use of the high molecular weight iron dextran. 49

Anaphylactoid reactions have predominantly been reported with the use of iron dextran. ${ }^{50,51}$ The use of iron dextran has especially been associated with allergic reactions. ${ }^{52,53}$ One case of severe intravascular hemolysis and acute renal failure following intravenous administration of iron dextran has been reported. 54

A multicenter phase IV clinical trial examined the safety of iron sucrose for the treatment of iron deficiency and for the maintenance of iron sufficiency in hemodialysis patients. Six hundred sixty-five hemodialysis patients, including 80 who had experienced previous intolerance to other parenteral iron preparations, received a total of 8,583 doses of iron sucrose. One hundred eighty-eight patients received more than one intravenous iron cycle (replacement, maintenance, or both). There were no serious or life-threatening drug-related adverse events. This study reached the conclusion that iron sucrose is safe when given as treatment for iron deficiency or for maintenance of iron stores. 55

One multicenter, randomized, double blind, placebo-controlled prospective comparative study performed in hemodialysis patients requiring at least $125 \mathrm{mg}$ of elemental iron concluded sodium ferric gluconate complex is well tolerated when given by intravenous push without a test dose. Sodium ferric gluconate complex has a significantly lower incidence of drug intolerance and life-threatening events as compared to previous studies using iron dextran. The routine use of iron dextran in hemodialysis patients should be discontinued. ${ }^{51}$

The North American clinical trials for iron sucrose injection study examined the effect of intravenous iron sucrose in 23 hemodialysis patients with documented sensitivity to iron dextran. Results showed no serious adverse drug reactions after a total of 223 doses of iron sucrose (184 doses by intravenous push, 39 doses by intravenous infusion). The study concluded that iron sucrose injection is safe and effective in the management of anemia in patients sensitive to iron dextran and can be administered without a test dose by intravenous push or infusion. 56

A randomized trial of 38 hemodialysis patients that compared iron sucrose and sodium ferric gluconate complex for 6 months found that these agents were equally effective and safe. 57 However, serum sickness effects of iron (the arthralgia-myalgia syndrome) may still be seen. Bielory et al ${ }^{58}$ describes a case of a serum sickness syndrome with cutaneous vasculitis in a patient given an intravenous iron dextran infusion. In Auerbach et $\mathrm{al}^{43}$ total-dose infusion study, $40 \%$ of treated patients develop arthralgia-myalgia syndrome. In a randomized, double blind, prospective study, 65 patients were administered methylprednisolone to prevent this complication. Data show that administration of methylprednisolone before and after infusion of iron dextran reduces the frequency and severity of the arthralgia-myalgia syndrome. Auerbach et $\mathrm{al}^{45}$ recommended that $125 \mathrm{mg}$ intravenous methylprednisolone should be given routinely before and after infusion of iron dextran.

Moniem et $\mathrm{al}^{46}$ performed an observational study of CKD patients and a prospective crossover study in hemodialysis patients to examine the comparative safety and tolerability of low molecular weight iron dextran and iron sucrose. They reached the conclusion that both iron formulations were equally safe and effective. ${ }^{46} \mathrm{Sav}$ et $\mathrm{al}^{59}$ in a randomized control trial compared low molecular weight iron dextran with iron sucrose in 60 patients, 30 in each group. There were 11 adverse reactions in the low molecular weight iron dextran group and 13 in the iron sucrose group. They concluded that the incidence of side effects associated with low molecular weight iron dextran was not different than that of iron-sucrose. ${ }^{59}$ Critchley and Dundar ${ }^{60}$ in a thorough systematic review assessed the frequency of adverse drug events associated with low molecular weight iron dextran and iron sucrose. Serious adverse events were rare with either low molecular weight iron dextran or iron sucrose. Two studies showed similar rates of adverse drug events between iron sucrose and low molecular weight iron dextran, two studies showed little difference between iron sucrose and iron gluconate, and one large review found a reduced risk on low molecular weight iron dextran compared with iron gluconate. Several studies showed lower risks of adverse drug events in low molecular weight iron dextran compared with high molecular weight iron dextran. ${ }^{60}$ Based on the results of these studies, the comparison of the iron sucrose and low molecular weight iron dextran showed no difference in toxicity or efficacy but considerable savings and ease of administration with low molecular weight iron dextran.

Infection and Intravenous Iron. The role of iron in bacterial growth and the pathophysiology of cellular immunity create legitimate, yet theoretical, concerns that active infection may be exacerbated by the administration of intravenous iron. Microorganisms require iron for survival. ${ }^{61}$ The patients on hemodialysis have neutrophil dysfunction due to many factors like malnutrition, increased intracellular calcium, the dialysis treatment per se, and low and high molecular weight circulating plasma factors. ${ }^{62}$ In hemodialysis patients ${ }^{63,64}$ and healthy individuals, ${ }^{64}$ in vitro studies show suppression of phagocytosis by iron. It is this process that is invoked to explain the increased susceptibility to infection of hemodialysis patients. ${ }^{65-68}$ Human data relating to this issue are limited. A few small, human studies in a population with CKD suggest a possible increased risk of developing an infection associated 
with intravenous iron; however, prospective human data directly linking intravenous iron to exacerbation of existing infection or infection-related mortality are lacking. Teehan et $\mathrm{al}^{69}$ followed 132 hemodialysis patients up to 1 year after the initiation of intravenous iron therapy for the outcome of bacteremia. Iron-replete patients (those with a transferrin saturation value $\geq 20 \%$ and a ferritin level $\geq 100 \mu \mathrm{g} / \mathrm{L}$ ) had a significantly higher risk for bacteremia as compared with hemodialysis patients who were not iron replete. In contrast, with more recent studies conclusive evidence that intravenous iron therapy as currently practiced is not associated with an increased risk of infection in hemodialysis patients derives from results of both prospective and retrospective clinical trials. According to the EPIBACDIAL (Epidemiology of Bacteremia in Dialysis Patients) observational trial study in which the investigators tried to find out the incidence and risk factors for bacteremia in 988 dialysis patients who were followed for 6 months each in 19 hemodialysis units, the risk of bacteremia was related to neither the serum ferritin nor the administration of intravenous iron therapy (iron dextran). Catheters were found to be the leading risk factor of bacteremia in chronic hemodialysis patients. The most common agent isolated in bacteremic patients was Staphylococcus aureus. ${ }^{66}$ In a multicenter, clinical trial of intravenous iron sucrose given in both replacement and maintenance dosing regimens, infection-related hospitalization was not increased among 665 hemodialysis patients who received 8,583 doses of intravenous iron sucrose. ${ }^{55}$ One hundred fifty-seven hemodialysis patients in the normal hemoglobin arm of the Scandinavian Hemoglobin Normalization Trial required high doses of iron sucrose but showed no increase in mortality or hospitalization when compared with patients in the subnormal hemoglobin arm. Specifically, there was no difference in iron sucrose dose between survivors and nonsurvivors in either the normal or the subnormal hemoglobin group. ${ }^{70}$ Another study showed no difference in either hospitalization or infection in patients who had ESRD and a ferritin level $>658 \mu \mathrm{g} / \mathrm{L} .{ }^{14}$

Cardiovascular Events and Intravenous Iron. Dialysis patients are in a state of inflammation, oxidative stress, increased incidence of infection and accelerated atherosclerosis. ${ }^{71}$ Biologically active iron plays a role in each of these processes. All iron agents including iron dextran, ${ }^{72}$ iron sucrose, ${ }^{72,73}$ and ferric gluconate ${ }^{72-74}$ shows evidence of bioactive iron release. Persistent oxidative stress in CKD patients promotes inflammation and, in turn, tissue injury, atherogenesis, and increased cardiovascular morbidity and mortality. ${ }^{75}$ Acute iron administration, whether intravenous ${ }^{76,77}$ or oral, ${ }^{78,79}$ clearly generates evidence of oxidative stress. An exacerbation of oxidative stress occurs after intravenous infusion of iron sucrose in dialysis patients, as demonstrated by an increase in plasma concentrations of malondialdehyde, ${ }^{80}$ which is a marker of lipid peroxidation. ${ }^{81}$ Ferric gluconate modifies $\beta 2$-microglobulin ${ }^{82}$ and fibrinogen ${ }^{74}$ as a marker for oxidative stress.
The serum ferritin reflects the burden of both tissue iron and systemic inflammation. ${ }^{20}$ Ferritin levels $>600 \mathrm{ng} / \mathrm{mL}$ in dialysis-dependent CKD patients are associated with evidence of a reciprocal elevation of lipid peroxidation and depression of antioxidant defense. ${ }^{80}$ The higher the dose of intravenous iron administered to dialysis patients, the greater the total body iron burden, the higher the serum ferritin level, 83 and the greater the evidence of oxidant stress. ${ }^{80,84}$ Persistent oxidative stress in CKD patients promotes inflammation and, in turn, tissue injury, atherogenesis, and increased cardiovascular morbidity and mortality. ${ }^{75}$

Iron Overload and Tissue Damage. Iron stores in the body are $<1 \mathrm{~g}$ and the storage limit of the reticuloendothelial system is exceeded at approximately $5 \mathrm{~g}$ of iron with overflow into parenchymal cells. ${ }^{85}$ Blood transfusions and excessive intravenous iron administration are the major causes of iron accumulation in ESRD. In CKD erythropoietin deficiency results in the downregulation of surface transferrin receptors. This leads to a shift of iron from red blood cells into reticuloendothelial system stores, where they are deposited, hepatocytes, and Kupffer cells. ${ }^{86}$ Iron overload has been demonstrated in biopsies of marrow and liver of untreated hemodialysis patients. ${ }^{87}$ Different methods are available for the diagnosis of iron load. These could be invasive like the assessment of the hepatic iron index in a liver biopsy specimen, "the gold standard," or noninvasive imaging techniques like computed tomography, magnetic resonance imaging, and magnetic susceptibility measurement. ${ }^{88,89}$ Gokal et $\mathrm{al},{ }^{90}$ in the pre-epoetin era, reported the distribution of serum ferritin levels in 120 maintenance hemodialysis patients who had received periodic blood transfusions and parenteral iron dextran. In nearly $71 \%$ of subjects, ferritin levels exceeded $800 \mathrm{ng} / \mathrm{mL}$. More than half the study population had ferritin levels exceeding $1000 \mathrm{ng} / \mathrm{mL}$, a level generally reflecting iron overload. Hepatic and splenic iron was detected postmortem in 16 of 22 individuals who had elevated iron burden that averaged $8.8 \mathrm{~g}$. However, hepatic fibrosis was present in a single patient. Iron was present in the cardiac myocytes of five patients, but there was no evidence of fibrosis. From the above study, it is evident that parenchymal injury from iron overloading is exceedingly difficult to achieve.

Erythropoietin stimulates erythropoiesis in the anemic patient and induces synthesis and expression of transferrin receptors on the cell surface by activating iron regulatory protein-1. Iron regulatory protein-1 stabilizes the messenger RNA of the transferrin receptor for its subsequent translation to receptor protein. ${ }^{91}$ This results in the uptake of iron by the erythron, which reduces the chances of iron deposition in nonerythroid tissues. Erythropoietin treatment results in a decrease in serum ferritin levels. ${ }^{92}$ Because of erythropoietin therapy, very few dialysis patients are iron overloaded as compared to those without erythropoietin treatment. However, iron overload may still occur when one of several specific circumstances occurs. This is a continued requirement for 
blood transfusions, an inability to be successfully treated with erythropoietin, and the presence of the hemochromatosis gene. ${ }^{93}$

Iron and Nephrotoxicity. Zager et al 72 in a comparative study of cytotoxic potentials of four iron formulations, iron dextran, iron sucrose, iron gluconate, and iron oligosaccharide, concluded that iron sucrose is a highly potent pro-oxidant capable of inducing tubular and endothelial cell death and then ferric gluconate, while iron dextran is the least. Zager et al ${ }^{94}$ again did a similar study and found similar results both in vivo and in vitro that iron sucrose is more toxic than iron dextran. Agarwal et al ${ }^{81}$ in a randomized controlled trial concluded that intravenous iron produces oxidative stress that is associated with transient proteinuria and tubular damage. Sanai et al ${ }^{95}$ administered intraperitoneal iron sucrose to 7 rats, and a second group of rats $(\mathrm{n}=5)$ were given iron dextran in the same dosage. They detected reductions in the tubular resorption of phosphorus, as well as hypophosphatemia and hypocalcemia, in animals treated with iron sucrose. Furthermore, lower serum albumin concentrations and hyponatremia were observed in animals treated with iron sucrose. These results demonstrate that iron sucrose is more toxic to renal-tubule function than is iron dextran. ${ }^{95}$ Pai et al ${ }^{96}$ showed increased non-transferrin-bound (free) iron and markers of oxidative stress after a single dose of either iron sucrose or ferric gluconate compared with iron dextran. ${ }^{96}$ These studies show that in vitro injury can be expressed at clinically relevant iron concentrations, and that in vivo glomerular iron deposition/injury may result. It is evident from these studies that for patients with stages 3 and 4 CKD, potential for nephrotoxicity is greater with the iron sucrose or iron gluconate compared to iron dextran.

\section{CONCLUSION}

In general, with the exception of high molecular weight iron dextran, serious or life-threatening adverse events appeared rare. Iron sucrose, ferric gluconate, and low molecular weight iron dextran can be given without significant risk of anaphylaxis, but only the last agent can be administered as a total-dose infusion. ${ }^{97}$ The Revised European Best Practice Guidelines do not recommend the use of iron dextran formulations. ${ }^{98}$ A number of studies document that anaphylaxis, the serious adverse event associated with iron dextran, is largely due to the two high molecular weight products, Imferon, which is no longer available, and Dexferrum, which is not recommended. $40,42,48,49,53,99-106$ Iron sucrose has the least reported adverse events and high molecular weight iron dextran has the highest number of reported adverse events. Low molecular weight iron dextran and ferric gluconate fall in between these two for the number of adverse drug events. ${ }^{40,46,48,56,60,98}$ Anaphylactic reactions have predominantly been reported with the use of iron dextran. ${ }^{50,51}$ Comparisons of the iron sucrose or iron gluconate to low molecular weight iron dextran show no difference in toxicity or efficacy but considerable savings and ease of administration with low molecular weight iron dextran. Low molecular weight iron dextran (InFed) is quite safe and substantially less costly than either iron sucrose or iron gluconate. ${ }^{52}$ Ferric gluconate and iron sucrose may also be safe among patients who are allergic to or intolerant of iron dextran. ${ }^{40,55,56,107}$ Clinical data, however, are conflicting in the association between iron and infection. Oxidative stress should not be considered as barrier to administration of continued intravenous iron. ${ }^{107}$ Current evidence on the role between intravenous iron in increasing the incidence of infection and oxidative stress deserves special consideration. Erythropoietin therapy decreases the incidence of iron overload as compared to no erythropoietin therapy. ${ }^{92}$ Potential for nephrotoxicity is greater with the iron sucrose or iron gluconate compared to iron dextran. ${ }^{72,81,94-96}$

\section{KEY ISSUES}

- $\quad$ CKD is a worldwide public health problem. Anemia represents a significant burden in renal disease, and is associated with increased cardiovascular morbidity and mortality, reduced quality of life and accelerated renal disease progression.

- Availability of iron is key for optimal erythropoiesis. Iron deficiency develops in virtually all dialysis patients receiving erythropoietin unless supplemental iron therapy is given orally or intravenously.

- Iron sucrose has the least reported adverse events and high molecular weight iron dextran has the highest number of reported adverse events. Low molecular weight iron dextran and ferric gluconate fall in between these two for the number of adverse drug events.

- Current evidence on the role between intravenous iron in increasing the incidence of infection and oxidative stress deserves special consideration. Oxidative stress should not be considered as a barrier to administration of continued intravenous iron.

- Erythropoietin therapy decreases the incidence of iron overload compared with no erythropoietin therapy.

- In patients with stages 3 and $4 \mathrm{CKD}$, the potential for nephrotoxicity is greater with the iron sucrose or iron gluconate compared to iron dextran.

\section{REFERENCES}

1. National Kidney Foundation. K/DOQI clinical practice guidelines for chronic kidney disease: evaluation, classification, and stratification. Am J Kidney Dis 2002;39 (2 Suppl 1):S1-266.

2. U.S. Renal Data System, USRDS 2005 Annual Data Report: Atlas of End-Stage Renal Disease in the United States, National Institutes of Health, National Institute of Diabetes and Digestive and Kidney Diseases, Bethesda, MD, 2005. Available at: http://www.usrds.org/adr.htm.

3. U.S. Renal Data System, USRDS 2000 Annual Data Report: Atlas of End-Stage Renal Disease in the United States, National Institutes of Health, National Institute of Diabetes and Digestive and Kidney Diseases, Bethesda, MD, June 2000. Available at: http://www.usrds.org/adr.htm 
4. Strippoli GF, Navaneethan SD, Craig JC. Haemoglobin and haematocrit targets for the anaemia of chronic kidney disease. Cochrane Database Syst Rev 2006;18:CD003967.

5. World Health Organization. Nutritional Anaemias: Report of a WHO Scientific Group. Geneva, Switzerland: World Health Organization, 1968.

6. Levin A, Thompson CR, Ethier J, Carlisle EJ, Tobe S, Mendelssohn D, Burgess E, Jindal K, Barrett B, Singer J, Djurdjev O. Left ventricular mass index increase in early renal disease: impact of decline in hemoglobin. Am J Kidney Dis 1999;34:125-134.

7. Jurkovitz CT, Abramson JL, Vaccarino LV, Weintraub WS, McClellan WM. Association of high serum creatinine and anemia increases the risk of coronary events: results from the prospective community-based atherosclerosis risk in communities (ARIC) study. J Am Soc Nephrol 2003;14: 2919-2925.

8. McClellan WM, Flanders WD, Langston RD, Jurkovitz C, Presley R. Anemia and renal insufficiency are independent risk factors for death among patients with congestive heart failure admitted to community hospitals: a population-based study. J Am Soc Nephrol 2002;13:1928-1936.

9. Ma JZ, Ebben J, Xia H, Collins AJ. Hematocrit level and associated mortality in hemodialysis patients. J Am Soc Nephrol 1999; 10:610-619.

10. Collins AJ, Ma JZ, Ebben J. Impact of hematocrit on morbidity and mortality. Semin Nephrol 2000;20:345-349.

11. Righetti M, Ferrario GM, Milani S, Serbelloni P, Sessa A. A single centre study about the effects of HFR on anemia. G Ital Nefrol. 2004;21 (Suppl 30):S168-171.

12. Hörl WH. Clinical aspects of iron use in the anemia of kidney disease. J Am Soc Nephrol 2007;18:382-393.

13. IV. NKF-K/DOQI Clinical Practice Guidelines for Anemia of Chronic Kidney Disease: update 2000. Am J Kidney Dis 2001;37 (Suppl 1):S182-238.

14. Besarab A, Amin N, Ahsan M, Vogel SE, Zazuwa G, Frinak S, Zazra JJ, Anandan JV, Gupta A. Optimization of epoetin therapy with intravenous iron therapy in hemodialysis patients. J Am Soc Nephrol 2000;11:530-538.

15. Coyne DW, Kapoian T, Suki W, Singh AK, Moran JE, Dahl NV, Rizkala AR; DRIVE Study Group. Ferric gluconate is highly efficacious in anemic hemodialysis patients with high serum ferritin and low transferrin saturation: results of the Dialysis Patients' Response to IV Iron with Elevated Ferritin (DRIVE) Study. J Am Soc Nephrol 2007;18:975-984.

16. Wish JB. Assessing iron status: beyond serum ferritin and transferrin saturation. Clin J Am Soc Nephrol 2006; Suppl 1:S4-8.

17. Tonelli M, Blake PG, Muirhead N. Predictors of erythropoietin responsiveness in chronic hemodialysis patients. ASAIO J 2001;47:82-85.

18. Brugnara C. Iron deficiency and erythropoiesis: new diagnostic approaches. Clin Chem 2003;49:1573-1578.

19. Fishbane S, Kalantar-Zadeh K, Nissenson AR. Serum ferritin in chronic kidney disease: reconsidering the upper limit for iron treatment. Semin Dial 2004;17:336-341.

20. Kalantar-Zadeh K, Rodriguez RA, Humphreys MH. Association between serum ferritin and measures of inflammation, nutrition and iron in haemodialysis patients. Nephrol Dial Transplant 2004;19:141-149.

21. Fishbane S, Kowalski EA, Imbriano LJ, Maesaka JK. The evaluation of iron status in hemodialysis patients. J Am Soc Nephrol 1996;7:2654-2657.

22. Locatelli F, Aljama P, Bárány P, Canaud B, Carrera F, Eckardt KU, Hörl WH, Macdougal IC, Macleod A, Wiecek A, Cameron S; European Best Practice Guidelines Working Group. Revised European best practice guidelines for the management of anaemia in patients with chronic renal failure. Nephrol Dial Transplant 2004;19 (Suppl 2):ii1-ii47.
23. KDOQI; National Kidney Foundation. II. Clinical practice guidelines and clinical practice recommendations for anemia in chronic kidney disease in adults. Am J Kidney Dis 2006;47 (5 Suppl 3):S11-145.

24. Danielson BG. Structure, chemistry, and pharmacokinetics of intravenous iron agents. J Am Soc Nephrol 2004;15 (Suppl 2):S93-98.

25. Agarwal R. Nonhematological benefits of iron. Am J Nephrol 2007;27:565-571.

26. Centers for Medicare and Medicaid Services, Kinney R. 2005 Annual Report: ESRD Clinical Performance Measures Project. Am J Kidney Dis 2006; 48 (4 Suppl 2):S1-106.

27. Macdougall IC, Tucker B, Thompson J, Tomson CR, Baker LR, Raine AE. A randomized controlled study of iron supplementation in patients treated with erythropoietin. Kidney Int 1996;50:1694-1699.

28. Markowitz GS, Kahn GA, Feingold RE, Coco M, Lynn RI. An evaluation of the effectiveness of oral iron therapy in hemodialysis patients receiving recombinant human erythropoietin. Clin Nephrol 1997;48:34-40.

29. Fudin R, Jaichenko J, Shostak A, Bennett M, Gotloib L. Correction of uremic iron deficiency anemia in hemodialyzed patients: a prospective study. Nephron 1998;79:299-305.

30. Ahsan N. Intravenous infusion of total dose iron is superior to oral iron in treatment of anemia in peritoneal dialysis patients: a single-center comparative study. J Am Soc Nephrol 1998;9:664-668.

31. Vychytil A, Haag-Weber M. Iron status and iron supplementation in peritoneal dialysis patients. Kidney Int Suppl 1999;69:S71-78.

32. Johnson DW, Herzig KA, Gissane R, Campbell SB, Hawley $\mathrm{CM}$, Isbel NM. Oral versus intravenous iron supplementation in peritoneal dialysis patients. Perit Dial Int 2001;21 (Suppl 3):S231-235.

33. Van Wyck DB, Roppolo M, Martinez CO, Mazey RM, McMurray S, for the United States Iron Sucrose (Venofer) Clinical Trials Group. A randomized, controlled trial comparing IV iron sucrose to oral iron in anemic patients with nondialysis-dependent CKD. Kidney Int 2005;68: 2846-2856.

34. Agarwal R, Rizkala AR, Bastani B, Kaskas MO, Leehey DJ, Besarab A. A randomized controlled trial of oral versus intravenous iron in chronic kidney disease. Am J Nephrol 2006;26:445-454.

35. Paschen HW. Efficient anaemia treatment with large intravenous iron doses. Geburtshilfe Frauenheilkunde 1949;9:604-616.

36. Chandler G, Harchowal J, Macdougall IC. Intravenous iron sucrose: establishing a safe dose Am J Kidney Dis 2001;38:988-991.

37. Hadnagy C, Márkus T, Szurkos I. Sideroblast content of the bone marrow at the end of pregnancy or 1st days of puerperium, respectively. Zentralbl Gynakol 1977;99: 1106-1107.

38. Hadnagy C, Andreicut S, Binder P. Geophagia sideropenica. Folia Haematol Int Mag Klin Morphol Blutforsch 1977;104:648-655.

39. McCurdy PR, Rath CE, Meerkrebs GE. Parenteral iron therapy: with special reference to a new preparation for intramuscular injection. N Engl J Med 1957;257:1147-1153.

40. Auerbach M, Rodgers GM. Intravenous iron. N Engl J Med 2007;357:93-94.

41. Marchasin S, Wallerstein RO. The treatment of iron-deficiency anemia with intravenous iron dextran. Blood 1964;23: 354-358.

42. Rodgers GM, Auerbach M, Cella D, Chertow GM, Coyne DW, Glaspy DW, Henry DH. High-molecular weight iron dextran: a wolf in sheep's clothing? J Am Soc Nephrol 2008;19: 833-834. 
43. Auerbach M, Witt D, Toler W, Fierstein M, Lerner RG, Ballard $\mathrm{H}$. Clinical use of the total dose infusion of iron dextran. J Lab Clin Med 1988;111:566-570.

44. Auerbach M, Winchester J, Wahab A, Richards K, McGinley M, Hall F, Anderson J, Briefel G. A randomized trial of three iron dextran infusion methods for anemia in EPO-treated dialysis patients. Am J Kidney Dis 1998;31:81-86.

45. Auerbach M, Chaudhry M, Goldman H, Ballard H. Value of methylprednisolone in prevention of the arthralgia-myalgia syndrome associated with the total dose infusion of iron dextran: a double blind randomized trial. J Lab Clin Med 1998;131:257-260.

46. Moniem KA, Bhandari S. Tolerability and efficacy of parenteral iron therapy in hemodialysis patients, a comparison of preparations. Transfusion Altern Transfusion Med 2007;9:37-42. doi: 10.1111/j.1778-428X.2007.00050.x.

47. Hamstra RD, Block MH, Schocket AL. Intravenous iron dextran in clinical medicine. JAMA 1980;243:1726-1731.

48. Chertow, GM, Mason, PD, Vaage-Nilsen, O, Ahlmén, J. On the relative safety of parenteral iron formulations. Nephrol Dial Transplant 2004;19:1571-1575.

49. Chertow GM, Mason PD, Vaage-Nilsen O, Ahlmén J. Update on adverse drug events associated with parenteral iron. Nephrol Dial Transplant 2006;21:378-382.

50. Cavill I. Intravenous iron as adjuvant therapy: a two-edged sword? Nephrol Dial Transplant 2003;18 (Suppl 8): viii24-viii28.

51. Michael B, Coyne DW, Fishbane S, Folkert V, Lynn R, Nissenson AR, Agarwal R, Eschbach JW, Fadem SZ, Trout JR, Strobos J, Warnock DG; Ferrlecit Publication Committee. Sodium ferric gluconate complex in hemodialysis patients: adverse reactions compared to placebo and iron dextran. Kidney Int 2002;61:1830-1839.

52. Faich G, Strobos J. Sodium ferric gluconate complex in sucrose: safer intravenous iron therapy than iron dextrans. Am J Kidney Dis 1999;33:464-470.

53. Coyne DW, Adkinson NF, Nissenson AR, Fishbane S, Agarwal R, Eschbach JW, Michael B, Folkert V, Batlle D, Trout JR, Dahl N, Myirski P, Strobos J, Warnock DG; Ferlecit Investigators. Sodium ferric gluconate complex in hemodialysis patients. II. Adverse reactions in iron dextran-sensitive and dextran-tolerant patients. Kidney Int 2003;63:217-224.

54. Buus NH, Jensen JD. Severe intravascular haemolysis and acute renal failure following intravenous administration of iron dextran. Nephrol Dial Transplant 2007;22:661-662.

55. Aronoff GR, Bennett WM, Blumenthal S, Charytan C, Pennell JP, Reed J, Rothstein M, Strom J, Wolfe A, Van Wyck D, Yee J; United States Iron Sucrose (Venofer) Clinical Trials Group. Iron sucrose in hemodialysis patients: safety of replacement and maintenance regimens. Kidney Int 2004;66:1193-1198.

56. Van Wyck DB, Cavallo G, Spinowitz BS, Adhikarla R, Gagnon S, Charytan C, Levin N. Safety and efficacy of iron sucrose in patients sensitive to iron dextran: North American Clinical Trial. Am J Kidney Dis 2000;36:88-97.

57. Sheashaa H, El-Husseini A, Sabry A, Hassan N, Salem A, Khalil A, El-Agroudy A, Sobh M. Parenteral iron therapy in treatment of anemia in end-stage renal disease patients: a comparative study between iron saccharate and gluconate. Nephron Clin Pract 2005;99:c97-101.

58. Bielory L. Serum sickness from iron-dextran administration. Acta Haematol 1990;83:166-168.

59. Sav T, Tokgoz B, Sipahioglu MH, Deveci M, Sari I, Oymak O, Utas C. Is there a difference between the allergic potencies of the iron sucrose and low molecular weight iron dextran? Ren Fail 2007;29:423-426.
60. Critchley J, Dundar Y. Adverse events associated with intravenous iron infusion (low-molecular-weight iron dextran and iron sucrose): a systematic review. Transfusion Altern Transfusion Med 2007;9:8-36. doi: 10.1111/j.1778-428X.2007.00042.x.

61. Parkkinen J, von Bonsdorff L, Peltonen S, Grönhagen-Riska C, Rosenlöf K. Catalytically active iron and bacterial growth in serum of haemodialysis patients after i.v. iron-saccharate administration. Nephrol Dial Transplant 2000;15: 1827-1834.

62. Sengoelge G, Kletzmayr J, Ferrara I, Perschl A, Hörl WH, Sunder-Plassmann G. Impairment of transendothelial leukocyte migration by iron complexes. J Am Soc Nephrol 2003;14:2639-2644.

63. Patruta SI, Edlinger R, Sunder-Plassmann G, Hörl WH. Neutrophil impairment associated with iron therapy in hemodialysis patients with functional iron deficiency. $\mathrm{J}$ Am Soc Nephrol 1998;9:655-663.

64. Ward CG, Hammond JS, Bullen JJ. Effect of iron compounds on antibacterial function of human polymorphs and plasma. Infect Immun 1986;51:723-730.

65. Hoen B, Kessler M, Hestin D, Mayeux D. Risk factors for bacterial infections in chronic haemodialysis adult patients: a multicentre prospective survey. Nephrol Dial Transplant 1995; 10:377-381.

66. Hoen B, Paul-Dauphin A, Hestin D, Kessler M. EPIBACDIAL: a multicenter prospective study of risk factors for bacteremia in chronic hemodialysis patients. J Am Soc Nephrol 1998;9:869-876.

67. Seifert A, von Herrath D, Schaefer K. Iron overload, but not treatment with desferrioxamine favours the development of septicemia in patients on maintenance hemodialysis. Q J Med 1987;65:1015-1024.

68. Kessler M, Hoen B, Mayeux D, Hestin D, Fontenaille C. Bacteremia in patients on chronic hemodialysis. A multicenter prospective survey. Nephron 1993;64:95-100.

69. Teehan GS, Bahdouch D, Ruthazer R, Balakrishnan VS, Snydman DR, Jaber BL. Iron storage indices: novel predictors of bacteremia in hemodialysis patients initiating intravenous iron therapy. Clin Infect Dis 2004;38:1090-1094.

70. Furuland H, Linde T, Ahlmén J, Christensson A, Strömbom U, Danielson BG. A randomized controlled trial of haemoglobin normalization with epoetin alfa in pre-dialysis and dialysis patients. Nephrol Dial Transplant 2003;18:353-361.

71. Locatelli F, Canaud B, Eckardt KU, Stenvinkel P, Wanner C, Zoccali C. Oxidative stress in end-stage renal disease: an emerging threat to patient outcome. Nephrol Dial Transplant 2003; 18:1272-1280.

72. Zager RA, Johnson AC, Hanson SY, Wasse H. Parenteral iron formulations: a comparative toxicologic analysis and mechanisms of cell injury. Am J Kidney Dis 2002;40: 90-103.

73. Esposito BP, Breuer W, Slotki I, Cabantchik ZI. Labile iron in parenteral iron formulations and its potential for generating plasma nontransferrin-bound iron in dialysis patients. Eur J Clin Invest 2002;32 (Suppl 1):42-49.

74. Michelis R, Gery R, Sela S, Shurtz-Swirski R, Grinberg N, Snitkovski T, Shasha SM, Kristal B. Carbonyl stress induced by intravenous iron during haemodialysis. Nephrol Dial Transplant 2003;18:924-930.

75. Himmelfarb J, Stenvinkel P, Ikizler TA, Hakim RM. The elephant in uremia: oxidant stress as a unifying concept of cardiovascular disease in uremia. Kidney Int 2002;62: 1524-1538.

76. Salahudeen AK, Oliver B, Bower JD, Roberts II LJ. Increase in plasma esterified F2-isoprostanes following intravenous iron infusion in patients on hemodialysis. Kidney Int 2001;60:1525-1531. 
77. Pollak A, Hayde M, Hayn M, Herkner K, Lombard KA, Lubec $\mathrm{G}$, Weninger M, Widness JA. Effect of intravenous iron supplementation on erythropoiesis in erythropoietin-treated premature infants. Pediatrics 2001;107:78-85.

78. Breuer W, Ronson A, Slotki IN, Abramov A, Hershko C, Cabantchik ZI. The assessment of serum nontransferrin-bound iron in chelation therapy and iron supplementation. Blood 2000;95:2975-2982.

79. Knutson MD, Walter PB, Ames BN, Viteri FE. Both iron deficiency and daily iron supplements increase lipid peroxidation in rats. J Nutr 2000;130:621-628.

80. Lim PS, Wei YH, Yu YL, Kho B. Enhanced oxidative stress in haemodialysis patients receiving intravenous iron therapy. Nephrol Dial Transplant 1999;14:2680-2687.

81. Agarwal R, Vasavada N, Sachs NG, Chase S. Oxidative stress and renal injury with intravenous iron in patients with chronic kidney disease. Kidney Int 2004;65:2279-2289.

82. Michelis R, Sela S, Kristal B. Intravenous iron-gluconate during haemodialysis modifies plasma beta2-microglobulin properties and levels. Nephrol Dial Transplant 2005;20: 1963-1969.

83. Hussein S, Prieto J, O'Shea M, Hoffbrand AV, Baillod RA, Moorhead JF. Serum ferritin assay and iron status in chronic renal failure and haemodialysis. Br Med J 1975; 1:546-548.

84. Drüeke T, Witko-Sarsat V, Massy Z, Descamps-Latscha B, Guerin AP, Marchais SJ, Gausson V, London GM. Iron therapy, advanced oxidation protein products, and carotid artery intima-media thickness in end-stage renal disease. Circulation 2002;106:2212-2217.

85. Schafer AI, Cheron RG, Dluhy R, Cooper B, Gleason RE, Soeldner JS, Bunn HF. Clinical consequences of acquired transfusional iron overload in adults. N Engl J Med 1981;304:319-324.

86. Eschbach Jr JW, Funk D, Adamson J, Kuhn I, Scribner BH, Finch CA. Erythropoiesis in patients with renal failure undergoing chronic dialysis. N Engl J Med 1967;276: 653-658.

87. Stivelman J, Schulman G, Fosburg M, Lazarus JM, Hakim RM. Kinetics and efficacy of deferoxamine in iron-overloaded hemodialysis patients. Kidney Int 1989;36:1125-1132.

88. Bassett ML, Halliday JW, Powell LW. Value of hepatic iron measurements in early hemochromatosis and determination of the critical iron level associated with fibrosis. Hepatology 1986;6:24-29.

89. Powell LW, Jazwinska E, Halliday J. Changing concepts of haemochromatosis. Adv Exp Med Biol 1994;356:285-291.

90. Gokal R, Millard PR, Weatherall DJ, Callender ST, Ledingham $\mathrm{JG}$, Oliver DO. Iron metabolism in haemodialysis patients. A study of the management of iron therapy and overload. Q J Med 1979;48:369-391.

91. Weiss G, Houston T, Kastner S, Jöhrer K, Grünewald K, Brock JH. Regulation of cellular iron metabolism by erythropoietin: activation of iron-regulatory protein and upregulation of transferrin receptor expression in erythroid cells. Blood 1997;89:680-687.

92. Eschbach JW, Abdulhadi MH, Browne JK, Delano BG, Downing MR, Egrie JC, Evans RW, Friedman EA, Graber SE, Haley NR, Korbet S; Krantz S; Lundin P; Nissenson A; Ogden D; Paganini E; Rader B; Rutsky E; Stivelman J. Recombinant human erythropoietin in anemic patients with end-stage renal disease: results of a phase III multicenter clinical trial. Ann Intern Med 1989;111:992-1000.

93. Cuthbert JA. Iron, HFE, and hemochromatosis update. J Invest Med 1997:45:518-529.

94. Zager RA, Johnson AC, Hanson SY. Parenteral iron nephrotoxicity: potential mechanisms and consequences. Kidney Int 2004;66:144-156.
95. Sanai T, Oochi N, Okada M, Imamura K, Okuda S, Iida M. Effect of saccharated ferric oxide and iron dextran on the metabolism of phosphorus in rats. J Lab Clin Med 2005;146:25-29.

96. Pai AB, Boyd AV, McQuade CR, Harford A, Norenberg JP, Zager PG. Comparison of oxidative stress markers after intravenous administration of iron dextran, sodium ferric gluconate and iron sucrose in patients undergoing hemodialysis. Pharmacotherapy 2007;27:343-350.

97. Auerbach M, Al Talib K. Low-molecular weight iron dextran and iron sucrose have similar comparative safety profiles in chronic kidney disease. Kidney Int 2008;73:528-530.

98. Locatelli F, Aljama P, Bárány P, Canaud B, Carrera F, Eckardt KU, Hörl WH, Macdougal IC, Macleod A, Wiecek A, Cameron S; European Best Practice Guidelines Working Group. Revised European Best Practice Guidelines for the management of anaemia in patients with chronic renal failure. Nephrol Dial Transplant 2004;19 (Suppl 2):ii1-ii47.

99. Case G. Maintaining iron balance with total-dose infusion of iron dextran. ANNA J 1998;25:65-68.

100. McCarthy JT, Regnier CE, Loebertmann CL, Bergstralh EJ. Adverse events in chronic hemodialysis patients receiving intravenous iron dextran--a comparison of two products. Am J Nephrol 2000;20:455-462.

101. Fletes R, Lazarus JM, Gage J, Chertow GM. Suspected iron dextran-related adverse drug events in hemodialysis patients. Am J Kidney Dis 2001;37:743-749.

102. Mamula P, Piccoli DA, Peck SN, Markowitz JE, Baldassano $\mathrm{RN}$. Total dose intravenous infusion of iron dextran for irondeficiency anemia in children with inflammatory bowel disease. J Pediatr Gastroenterol Nutr 2002;34:286-290.

103. Silverstein SB, Rodgers GM. Parenteral iron therapy options. Am J Hematol 2004;76:74-78.

104. Auerbach M, Ballard H, Trout JR, McIlwain M, Ackerman A, Bahrain H, Balan S, Barker L, Rana J. Intravenous iron optimizes the response to recombinant human erythropoietin in cancer patients with chemotherapy-related anemia: a multicenter, open-label randomized trial. J Clin Oncol 2004;22:1301-1307.

105. Bailie GR, Clark JA, Lane CE, Lane PL. Hypersensitivity reactions and deaths associated with intravenous iron preparations. Nephrol Dial Transplant 2005;20:1443-1449.

106. Auerbach M, Ballard H, Glaspy J. Clinical update: intravenous iron for anemia. Lancet 2007;369:1502-1504.

107. Bailie GR, Johnson CA, Mason NA. Parenteral iron use in the management of anemia in end-stage renal disease patients. Am J Kidney Dis 2000;35:1-12.

\section{AUTHOR AFFILIATION}

Amir Hayat, $M D$

Department of Medicine, Division of Nephrology

SUNY Downstate Medical Center

Brooklyn, New York, USA 